\title{
Indirect somatic embryogenesis from transgenic immature leaf of safflower Carthamus tinctorius (Mohler, Roth, Schmidt \& Boudreaux, 1967) (Asterales: Asteraceae)
}

\section{S. Pradeep Kumar ${ }^{1}$ and B. D. Ranjitha Kumari ${ }^{2}$}

${ }^{1}$ Department of Postharvest Science. Institute of Postharvest and Food Sciences. The Volcani Center. Agriculture Research Organisation. POB 6. Bet Dagan - 50250. Israel. Email: pradeepkumar2k@gmail.com

${ }^{2}$ Stress Physiology \& Medicinal Plant Biotechnology Unit. Department of Plant Science. Bharathidasan University. Tiruchirappalli - 620024. Tamil Nadu. India.

\begin{abstract}
Highly efficient protocol is developed for indirect somatic embryogenesis from transgenic immature leaf of safflower Carthamus tinctorius (Mohler, Roth, Schmidt \& Boudreaux, 1967) (Asterales: Asteraceae) explants in solid culture. Here two different half strength mediums like MSG and EMM both were tested in addition to inorganic and organic nitrogen sources and also combination of the reference medium. Inorganic nitrogen source shows about 39.5 number of embryos with 37\% embryo germination and organic Nitrogen source like L-glutamine $(20 \mu \mathrm{M})$ on reference medium influenced 80.5 number of somatic embryos with $44.9 \%$ germination. However, maximum of 92.0 number of embryo induction with $52.5 \%$ germination was noticed on $\mathrm{CH}$ (casein hydrolysate) (1.5 mg/L) containing medium. Combination of inorganic and organic nitrogen sources like $\mathrm{NH}_{4} \mathrm{NO}_{3}(40 \mu \mathrm{M})$ in combinations with reduced form of organic nitrogen casein hydrolysate $(\mathrm{CH})(1.5 \mathrm{mg} / \mathrm{L})$ was found to be most suitable for induction of somatic embryos with a maximum of 117 number of somatic embryos with $60.9 \%$ germination in immature leaf explants. About 57\% plant conversion rate showed in NARI-6 cultivar after 2 weeks of culture. However it showed maximum plant conversion rate about $68 \%$ with basal medium along with $1.5 \%$ sucrose supplemented with $\mathrm{GA}_{3}(1.5 \mu \mathrm{M})$ and spermidine $(1.0 \mu \mathrm{M})$. Germinated embryos with shoot and root poles were isolated and subcultured on suitable root induction medium containing NAA $(2.5 \mu \mathrm{M})+\mathrm{AgNO}_{3}(1.5 \mu \mathrm{M})$ showed maximum rooting frequency of about $69.6 \%$.
\end{abstract}

Keywords: Chitinase gene; Hygromycin; Somatic Embryogenesis; Spermidine; Transgenic plantlets.

\section{Introduction}

Safflower Carthamus tinctorius (Mohler, Roth, Schmidt \& Boudreaux, 1967) (Asterales: Asteraceae) is cultivated mainly for its seed, which is used as edible oil and as birdseed. This crop was also grown for its flowers, used for colouring and flavouring foods and making dyes. It is a rich source of oil (35\%-40\%) and linoleic acid content (75\%-86\%) it demands a premium price among edible oils and is competitive from a health point of view with olive and canola oil (Dajue and 
Mündel, 1996). Further improvement, particularly using Agrobacterium-mediated transformation method has most widely been used for various plant species due to its easy feasibility without any special equipment was reported by (Sri Shilpa et al., 2010). Importance of co-cultivation and $\mathrm{pH}$ of medium are successful for Agrobacterium-mediated transformation of Lilium $x$ formolongi (Tanaka et al., 2000). There, in the absence of resistant cultivars, they can cause tremendous crop losses. Regeneration of plant is correlated with the ability of embryogenic callus formation. However, somatic embryos from embryogenic callus may not produce plant regeneration. In this respect, plant regeneration via somatic embryogenesis is preferred because it provides high rate of multiplication and often results in true-totype plants for transformation.

This process occurs through the same key stages of embryo development as zygotic embryogenesis (i.e. globular, heart and torpedo stages) (Sharma et al., 2004). There have been several reports that somatic embryogenesis is a multi-step regeneration process starting with formation of proembryogenic masses, followed by somatic embryo formation, maturation, desiccation and plant regeneration (Von Arnold et al., 2002). Two different pathways of somatic embryogenesis generally occur namely, directly without forming the callus phase (Chen et al., 2004; Zhang et al., 2005) and indirectly following callus formation from explants (Griga, 2002; Kim et al., 2003; Conde et al., 2004 ). Callus formation from direct embryogenesis, without the callus phase, is likely to be more suitable for mass propagation because genetic rearrangement is limited compared with the embryogenesis via calli, which often showed aberrant chromosome numbers during culture (Tanaka et al., 2000). In indirect somatic embryogenesis, embryogenic callus provide a large population of embryogenic competent cells that are extremely amenable for transformation by Agrobacterium. Each transformed cell represents an independent transgenic line, thus tremendously increasing the number of transformation events in a regenerable tissue and improving transformation frequencies were reported by (Leelavathi et al., 2004). The different medium strength along with nitrogen sources plays an important role for somatic embryogenesis in many plant species. Various effects of polyamines on somatic embryogenesis via mature embryo in wheat (Aydin et al., 2016).

The effects of different growth regulators on somatic embryogenesis from leaves of safflower have not been compared and studied. Furthermore, awareness of the cellular origin of somatic embryos is essential to determine the utility of the regeneration system for transformation. There have been no reports on histological origin of somatic embryos in safflower. It has been reported that various factors affecting on somatic embryogenesis of safflower $C$. tinctorius at morphological and biochemical levels were reported by (Pradeep Kumar and Ranjitha Kumari, 2011). The major role of nitrogen was included in the form of the basal inorganic and organic forms, comprising the three ionic forms (nitrate, ammonium and amine) available for uptake by the plant cells and tissues.

Hence, the aim of the present investigation was designed to establish a well developed protocol for somatic embryogenesis of safflower into fully acclimatized field plants from transgenic immature leaf explants.

\section{Material and methods}

\section{Plant materials}

In the present study seeds of safflower cultivar NARI-6 were used. Seeds were disinfected by $1.0 \%$ Teepol, $0.6 \%$ sodium hypochlorite solution treatment for $30 \mathrm{~s}$, and sterilized with tap water for $20 \mathrm{~min}$ to remove detergent. Further processes were carried out in laminar air flow chamber by treating with $70 \%$ ethanol $(\mathrm{v} / \mathrm{v})$ for $1 \mathrm{~min}$ and followed by repeated washing with sterile distilled water, followed by $0.1 \% \mathrm{HgCl}_{2}$ for $2 \mathrm{~min}$ and rinsed thrice with sterile distilled water for $2 \mathrm{~min}$. The surface sterilized seeds were 
inoculated on (Murashige and Skoog, 1962). The cultures were incubated in darkness for $24 \mathrm{~h}$ at $25 \pm 2{ }^{\circ} \mathrm{C}$ under white fluorescent light $\left(15 \mu \mathrm{mol} \mathrm{m}^{-2} \mathrm{~s}^{-1}\right)$ of $16 / 8 \mathrm{~h}$ photoperiod.

Development of indirect somatic embryogenesis and effect of media strength and nitrogen sources

Embryogenic callus induction and somatic embryogenesis was carried out with transgenic immature leaf explants. The transgenic immature leaf explants were excised into $0.5-1.0 \mathrm{~cm}$ segments and were subcultured on MS basal with 3.0\% sucrose, L-glutamine (200 $\mathrm{mg} / \mathrm{L})$, myo-inositol $(150 \mathrm{mg} / \mathrm{L})$, thiamine $\mathrm{HCl}$ (150 mg/L) and pyridoxine $\mathrm{HCl}(75 \mathrm{mg} / \mathrm{L})$ and medium also supplemented with TDZ (1.0-5.0 $\mu \mathrm{M})$ with combination of NAA, 2, 4-D, IBA ranging from (1.0-7.0 $\mu \mathrm{M})$. We used 30 explants and repeated thrice the experiment with the same culture conditions unless otherwise specified. In second experiment, half strength EMM medium supplemented with different ranges $(10,20,40$ and $60 \mu \mathrm{M})$ of individual inorganic nitrogen sources like $\mathrm{KNO}_{3}$, and $\mathrm{NH}_{4} \mathrm{NO}_{3}$ were tested. In third experiment, individual organic nitrogen sources L-glutamine, ranges of 10, 20, 40 and $60 \mu \mathrm{M}$ and casein hydrolysate $(\mathrm{CH})$ ranges from $0.5,1.0,1.5$ and $2.0 \mathrm{mg} / \mathrm{L}$ were tested. In forth experiment, EMM reference medium consisting of $\mathrm{NH}_{4} \mathrm{NO}_{3}(10,20,40$ and $60 \mu \mathrm{M})$ in combinations with $\mathrm{CH}(0.5$, $1.0,1.5$ and $2.0 \mathrm{mg} / \mathrm{L})$ or L-glutamine (0.5, $1.0,1.5$ and $2.0 \mu \mathrm{M})$ were tested. All the cultures were maintained in the same medium at $25 \pm 2{ }^{\circ} \mathrm{C}$ under white fluorescent light $\left(15 \mu \mathrm{mol} \mathrm{m} \mathrm{m}^{-2} \mathrm{~s}^{-1}\right)$ for the photoperiod of 10-12 h per day, and were subcultured every two weeks. All developmental stages of embryos were matured and germinated to cotyledon stage in the same medium. There were 40 replicates of explants per treatment, and the experiment was repeated thrice. Total number of somatic embryogenesis with per cent embryo germination was recorded every week end from the date of embryo formation.

\section{Callus initiation}

Transgenic immature leaves were excised carefully from 45 days old in vitro plantlets with the help of a sterilized surgical blade. The adaxial side of explants on MS basal medium salts, 3.0\% sucrose (w/v) (Murashige and Skoog, 1962) medium supplemented with different concentrations of TDZ (1.0-5.0 $\mu \mathrm{M})$ in combination with different ranges $(1.0-7.0 \mu \mathrm{M})$ of IBA, 2,4-D, and NAA as indicated on the tables. The cultures (10 $\mathrm{cm}^{3}$ of medium/25x100 mm culture tubes) were maintained at $25 \pm 2{ }^{\circ} \mathrm{C}$ under continuous irradiation with a white fluorescent light $\left(15 \mu \mathrm{mol} \mathrm{m} \mathrm{m}^{-2} \mathrm{~s}^{-1}\right)$ for a 10 to $12 \mathrm{~h}$ photoperiod. There were 30 replicates (explants) per treatment, were repeated thrice. After 2 weeks of Immature leaf culture callus was initiated from the cut end with same culture conditions.

\section{Embryogenic calli isolation and proliferation \\ Isolation and subculture of} pro-embryogenic callus from non-embryogenic callus clumps were done after three weeks. In each subculture, 5-7 pro-embryogenic cell clumps were cultured (approximately $0.5 \mathrm{~cm}^{3}$ each clumps) per $250 \mathrm{~mL}$ conical flask containing $50 \mathrm{~mL}$ fresh MS solid medium containing same PGRs composition and maintained under the same cultural conditions for the induction and proliferation of embryogenic callus. The embryogenic callus appeared with different color and shape after second subculture, and after 65 days of culture percentage of embryogenic callus was recorded.

Effect of MSG and EMM medium on somatic embryogenesis in solid culture

The transgenic immature leaf derived from embryogenic callus were isolated and subcultured approximately $50 \mathrm{mg}$ in half-strength EMM and MSG (Becwar et al., 1988) basal medium containing $0.8 \%$ agar $(\mathrm{w} / \mathrm{v})$ with $1.5 \%$ sucrose $(\mathrm{w} / \mathrm{v})$ for the maturation and induction of a high frequency of somatic 
embryos. After 2 weeks of culture the early appearance of globular, heart, torpedo and early cotyledonary stage embryos developed on the surface of the callus. There were maintained in the same medium at $25 \pm 2{ }^{\circ} \mathrm{C}$ for $16 \mathrm{~h}$ photoperiod to enhance the production of primary somatic embryos, and were subcultured at every week ends. The cotyledonary stage embryos were developed directly from the torpedo stage embryos, and were maintained on same cultural conditions medium for 30 days and total number of primary somatic embryos response were recorded. Primary somatic embryos were spread on solid medium in a sterile petridish inside the laminar flow hood and the different stages of (globular, heart, torpedo and cotyledon) embryos were separated out under microscope. Approximately 30 embryos were cultured on different culture bottles and tubes containing different medium strength. There were 15 culture bottles at the onset of the experiment and were subcultured once a week. All the stages of embryos of common lineage could be converted into PEM and cultures were incubated at $\left(25 \pm 2{ }^{\circ} \mathrm{C}\right)$ in the same medium for further proliferation. The embryo culture was routinely subcultured and repeated thrice in the same medium and after 90 days of culture the percentage of total number of embryos was recorded.

\section{Germination and subsequent plant regeneration}

All the stages of embryos were isolated from embryonic clumps, were cultured in $250 \mathrm{~mL}$ flasks containing $50 \mathrm{~mL}$ of fresh semi solid half strength EMM basal, $1.5 \%$ sucrose media fortified with spermidine $(0.2-2.0 \quad \mu \mathrm{M})$ and $\mathrm{GA}_{3}$ $(0.5-2.5 \mu \mathrm{M})$ for embryo maturation and germination. The experiments were done with 6 flasks and repeated thrice. After seven weeks the germination frequency was recorded. The culture was grown under white fluorescent tube $\left(15 \mu \mathrm{mol} \mathrm{m} \mathrm{m}^{-2} \mathrm{~s}^{-1}\right)$ for the photoperiod of $16 \mathrm{~h} /$ day and plant conversion rate was recorded after 10 days of culture. Matured germinated cotyledon stage embryos with root poles and non-root poles were placed on culture tubes each containing $15 \mathrm{~mL}$ half strength EMM basal salts, comprising of NAA (1.0-4.5 $\mu \mathrm{M})$ and $\mathrm{AgNO}_{3}(0.5-2.5 \mu \mathrm{M})$ for efficient rooting for 1 month. After that rooting results were recorded and experiment was repeated thrice. The adventitious roots from plantlets were carefully washed with tap water to remove agar gel, and then transferred to plastic pots with the mixture of sand, garden soil and vermiculite $(1: 2: 1 \mathrm{v} / \mathrm{v})$. Plants were reared in Plant Growth Chamber at $\left(25 \pm 2^{\circ} \mathrm{C}, 16 \mathrm{~h}\right.$ photoperiod under $30 \mu \mathrm{mol} \mathrm{m}^{-2} \mathrm{~s}^{-1}$ ) illumination for 10 days. After 2 weeks the acclimated plants were transplanted and set under green house conditions.

\section{Statistical analysis}

A completely Randomized Block Design (CRBD) was used in all the experiments and repeated thrice. Numbers of somatic embryos from transgenic immature leaf explants were tabulated. The pertaining to frequencies of embryogenic callus induction, somatic embryo formation, embryo germinations were subjected to analysis of variance test and mean separation was carried out using Duncan's Multiple Range Test (DMRT) at $\mathrm{P} \leq 0.05$ levels.

\section{Results}

\section{Efficacy of nitrogen source on indirect somatic embryogenesis \\ Inorganic nitrogen. The number} of somatic embryos produced when different inorganic nitrogen sources tested on half strength EMM reference medium. In transgenic indirect somatic embryogenesis from immature leaf showing about 39.5 number of embryos with 37\% embryo germination was noticed in immature leaf explants cultured on half strength EMM reference medium supplemented with inorganic nitrogen $\mathrm{KNO}_{3}(20 \mu \mathrm{M})$ after 65 days of culture. $\mathrm{NH}_{4} \mathrm{NO}_{3} \quad(40 \mu \mathrm{M})$ containing medium influenced 29.7 numbers of embryos with $30.5 \%$ germination in immature leaf explant culture (Table 1). 
Table 1. Effects of nitrogen sources on in direct somatic embryogenesis from immature leaf of C. tinctorius NARI-6.

\begin{tabular}{|c|c|c|}
\hline \multirow{2}{*}{ 1/2 EMM medium strength } & \multicolumn{2}{|c|}{ Immature leaf } \\
\hline & Mean no. of SE & Embryo germination (\%) \\
\hline \multirow{2}{*}{\multicolumn{3}{|c|}{ [Inorganic nitrogen] }} \\
\hline & & \\
\hline 10 & $22.3 \mathrm{jk}$ & 26.1 \\
\hline 20 & $39.5 \mathrm{~h}$ & 37.0 \\
\hline 40 & $32.8 \mathrm{hi}$ & 31.5 \\
\hline 60 & $26.2 \mathrm{ij}$ & 23.0 \\
\hline \multicolumn{3}{|l|}{$\mathrm{NH}_{4} \mathrm{NO}_{3}(\mu \mathrm{M})$} \\
\hline 10 & $20.1 \mathrm{k}$ & 24.4 \\
\hline 20 & $26.3 \mathrm{ij}$ & 27.7 \\
\hline 40 & $29.7 \mathrm{i}$ & 30.5 \\
\hline 60 & $24.4 \mathrm{j}$ & 23.0 \\
\hline \multicolumn{3}{|l|}{ [Organic nitrogen] } \\
\hline \multicolumn{3}{|l|}{ L-Glutamine $(\mu \mathrm{M})$} \\
\hline 10 & $66.3 \mathrm{gh}$ & 40.3 \\
\hline 20 & $80.5 \mathrm{f}$ & 44.9 \\
\hline 40 & $77.2 \mathrm{fg}$ & 43.5 \\
\hline 60 & $73.4 \mathrm{~g}$ & 41.9 \\
\hline \multicolumn{3}{|l|}{$\mathrm{CH}(\mathrm{mg} / \mathrm{L})$} \\
\hline 0.5 & $77.2 \mathrm{fg}$ & 44.5 \\
\hline 1.0 & $88.6 \mathrm{de}$ & 46.0 \\
\hline 1.5 & $92.0 \mathrm{~cd}$ & 52.5 \\
\hline 2.0 & 86.7 e & 46.5 \\
\hline \multicolumn{3}{|c|}{$\begin{array}{l}\text { [Inorganic and Organic nitrogen] } \\
\qquad \mathrm{NH}_{4} \mathrm{NO}_{3}(\mu \mathrm{M})+\mathrm{CH}(\mathrm{mg} / \mathrm{l})\end{array}$} \\
\hline 10 & $95.3 \mathrm{bc}$ & 54.7 \\
\hline 1.0 & $101 \mathrm{ab}$ & 57.0 \\
\hline 1.5 & $117 \mathbf{a}$ & 60.9 \\
\hline 2.0 & $98.0 \mathrm{~b}$ & 56.9 \\
\hline \multicolumn{3}{|c|}{$\mathrm{NH}_{4} \mathrm{NO}_{3}(\mu \mathrm{M})+$ L-Glutamine $(\mu \mathrm{M})$} \\
\hline $\begin{array}{ll}10 & 0.5\end{array}$ & $86.7 \mathrm{e}$ & 47.8 \\
\hline 1.0 & $94.3 \mathrm{c}$ & 54.0 \\
\hline $40 \quad 1.5$ & $89.5 \mathrm{~d}$ & 47.3 \\
\hline 2.0 & 85.4 ef & 45.5 \\
\hline
\end{tabular}

Those marked with the common letters within a column are not significantly different at $\mathrm{P} \leq 0.05$, according to Duncan's Multiple Range Test (DMRT).

Organic nitrogen. Half strength reference medium along with organic nitrogen sources produced greater number of somatic embryos in immature leaf explant culture. In these case, L-glutamine $(20 \mu \mathrm{M})$ on reference medium influenced 80.5 number of somatic embryos with $44.9 \%$ germination in immature leaf explants. However, maximum of 92.0 number of embryo induction with 52.5\% germination was noticed in immature leaf explants placed on $\mathrm{CH}$ (casein hydrolysate) (1.5 mg/L) containing medium (Table 1).

Inorganic and organic nitrogen. The combined action of inorganic and organic nitrogen sources influenced comparatively more number of somatic embryos from NARI-6 derived immature leaf explant. In case of reduced and 
oxidized form of inorganic nitrogen $\mathrm{NH}_{4} \mathrm{NO}_{3}(40 \mu \mathrm{M})$ in combinations with reduced form of organic nitrogen $\mathrm{CH}$ (casein hydrolysate) $(1.5 \mathrm{mg} / \mathrm{L})$ found better for maximum of 117 number of somatic embryos with $60.9 \%$ germination in immature leaf explants. Further study showed that $\mathrm{NH}_{4} \mathrm{NO}_{3}\left(\begin{array}{lll}20 & \mu \mathrm{M}\end{array}\right)$ and L-glutamine $(1.0 \mu \mathrm{M})$ containing medium produced 94.3 number of somatic embryo formation with 54\% germination in immature leaf explants (Table 1).

\section{Initiation and proliferation embryogenic calli}

The transgenic immature leaf explants induced primary callus after 18 days of culture in MS basal medium with $3.0 \%$ sucrose. Various concentrations of PGRs were tested for differences in obtaining calli as shown in (Table 2). In the early stage of embryogenesis experiment the color of the callus in the liquid media was greenish-brown, and then callus texture changed from soft to hard. After the subculture to the second medium, a yellowish, soft, friable callus began forming on the older brownish callus, from which somatic embryos later began differentiating (Figure 1a, b, c). TDZ alone produced white-creamy embryogenic callus in immature leaf explants. In half strength MS medium supplemented with TDZ $(4.0 \mu \mathrm{M})$ and NAA $\left(\begin{array}{lll}5.0 & \mu \mathrm{M})\end{array}\right)$ induced $44.0 \%$ embryogenic callusing response was observed in immature leaf explants. Immature leaf explants cultured on TDZ $(3.0 \mu \mathrm{M})$ plus 2, 4-D $(3.5 \mu \mathrm{M})$ supplemented produced $78.2 \%$ embryogenic callus induction (Table 2; Figure 1d). However, TDZ $(4.0 \mu \mathrm{M})$ plus IBA $(5.0 \mu \mathrm{M})$ combinations tested medium produced significantly higher with $95 \%$ of embryogenic callus in immature leaf explants after 70 days.

Table 2. Effect of culture medium on embryogenic callus production and germination from transgenic immature leaf of safflower C. tinctorius cv. NARI-6.

\begin{tabular}{lcc}
\hline \multirow{2}{*}{ Medium strength } & \multicolumn{2}{c}{ Immature leaf } \\
\cline { 2 - 3 } & Mean no. of SE/callus explants & Embryo germination (\%) \\
\hline H- MS & $7.6 \pm 0.5$ & $11.0 \pm 0.7$ \\
F- MS & $6.5 \pm 1.5$ & $8.5 \pm 1.2$ \\
H- EMM & $\mathbf{1 3 . 7 \pm 1 . 0}$ & $\mathbf{1 9 . 1} \pm 2.0$ \\
F- EMM & $2.3 \pm 2.0$ & $9.7 \pm 1.4$ \\
\hline
\end{tabular}

H-half strength; F-full strength, Values are mean \pm SE of three replicates.

Effect of MSG and EMM medium on somatic embryogenesis in solid culture

Isolation of $50 \mathrm{mg}$ of white and yellow creamy PEC were subcultured in PGRs-free half-strength EMM and MSG basal media in which it is proliferated and changed their morphological nature to form numerous embryos (globular, heart, torpedo and cotyledon) within 2-3 weeks of culture in all the two media tested (Figure 1e). In
NARI-6 cultivar, about 7.6 numbers of somatic embryos with $11 \%$ embryo germination response was observed from immature leaf calli (ILDEC) on half strength MSG solid medium after 30 days of culture. In this case, maximum of 13.7 numbers of embryos germination with $19.1 \%$ embryogenic response was greatest per immature leaf derived calli in half strength EMM medium (Table 2). 
Figure 1. Indirect somatic embryogenesis from transgenic immature leaf of safflower C. tinctorius (solid culture).
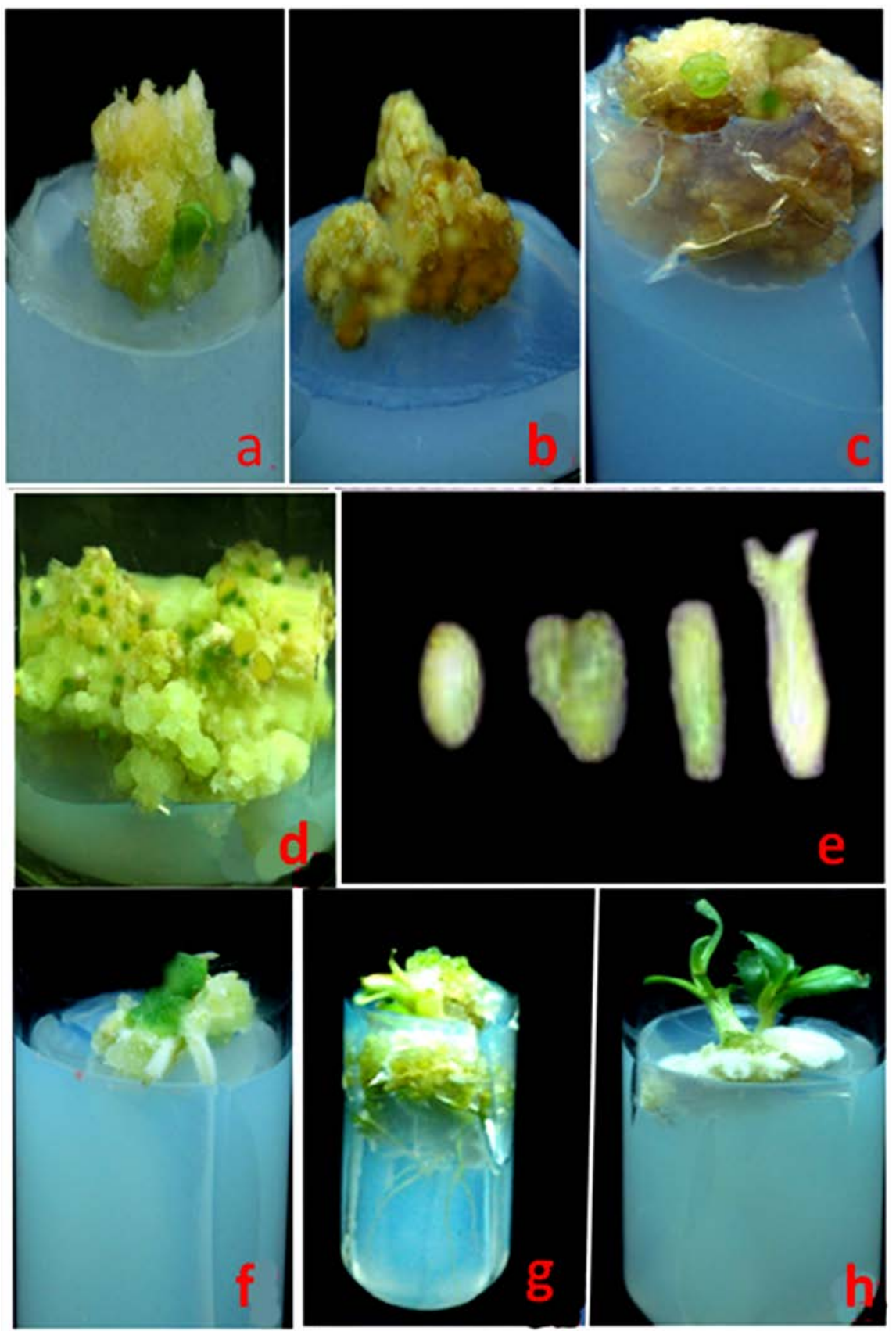

a- Embryogenic callus initiation from immature leaf explants; b-c-Embryo maturation and germination; d- Embryogenic callus induction from Immature leaf explants; e- Early globular, globular, heart and torpedo stage embryos; f- Shoot initiation from embryos; g- Shoot proliferation and root initiation; hRooting and shooting development.

\section{Development and maturation of embryos \\ Different stages of embryos turned to green immature cotyledon stages in}

semisolid medium and then cultured into germination medium under darkness from which mature cotyledon embryos produced distinct epicotyls with shoot pole and 
hypocotyls with root poles (Figure 1e, f). In the present system, about $50 \%$ embryo germination was observed on MSG basal salts, $1.5 \%$ sucrose medium supplemented with $\mathrm{GA}_{3}(1.5 \mu \mathrm{M})$ at the end of 6th week of culture. About 57\% plant conversion rate showed in NARI-6 cultivar after 2 weeks of culture. However it showed maximum plant conversion rate about 68\% with basal medium along with $1.5 \%$ sucrose supplemented with $\mathrm{GA}_{3}(1.5 \mu \mathrm{M})$ and Spermidine $(1.0 \mu \mathrm{M})$ (Table.3).

Table 3. Effect of spermidine and $\mathrm{GA}_{3}$ on embryo germination and conversion of plants in safflower C. tinctorius.

\begin{tabular}{|c|c|c|c|}
\hline \multirow{2}{*}{\multicolumn{2}{|c|}{$\begin{array}{c}\text { Medium } \\
\text { Composition }(\mu \mathrm{M})\end{array}$}} & \multicolumn{2}{|c|}{ NARI-6 } \\
\hline & & $\begin{array}{c}\text { Germination } \\
\text { frequency (\%) }\end{array}$ & Plant conversion rate $(\%)$ \\
\hline \multicolumn{2}{|c|}{$\mathrm{GA}_{3}$} & & \\
\hline \multicolumn{2}{|c|}{0.5} & 15 & 32 \\
\hline \multicolumn{2}{|c|}{1.0} & 22 & 46 \\
\hline \multicolumn{2}{|c|}{1.5} & 34 & 57 \\
\hline \multicolumn{2}{|c|}{2.0} & 30 & 47 \\
\hline \multicolumn{2}{|c|}{2.5} & 25 & 32 \\
\hline \multicolumn{4}{|c|}{$\mathrm{GA}_{3}+$ Spermidine } \\
\hline 0.5 & 0.2 & 21 & 42 \\
\hline & 0.5 & 32 & 56 \\
\hline 1.5 & 1.0 & 40 & 68 \\
\hline 2.0 & 1.5 & 35 & 59 \\
\hline 2.5 & 2.0 & 29 & 39 \\
\hline
\end{tabular}

Table 4. Effect of NAA in combinations with $\mathrm{AgNO}_{3}$ on frequency of rooting in transgenic somatic embryogenesis of safflower $C$. tinctorius.

\begin{tabular}{|c|c|c|c|}
\hline \multirow{2}{*}{\multicolumn{2}{|c|}{$\begin{array}{c}\text { Medium } \\
\text { Composition }(\mu \mathrm{M})\end{array}$}} & \multicolumn{2}{|c|}{ NARI-6 } \\
\hline & & $\begin{array}{c}\text { Mean No. of } \\
\text { Responsive plantlets }\end{array}$ & $\begin{array}{c}\text { Frequency of } \\
\text { rooting }(\%)\end{array}$ \\
\hline \multicolumn{2}{|c|}{ NAA } & & \\
\hline \multicolumn{2}{|c|}{1.0} & $16 \mathrm{e}$ & 20.0 \\
\hline \multicolumn{2}{|c|}{1.5} & $25 \mathrm{de}$ & 31.2 \\
\hline \multicolumn{2}{|c|}{2.5} & $30 \mathrm{~d}$ & 37.5 \\
\hline \multicolumn{2}{|c|}{3.0} & 39 c & 48.8 \\
\hline \multicolumn{2}{|c|}{4.5} & 15 ef & 18.7 \\
\hline \multicolumn{4}{|c|}{$\mathrm{NAA}+\mathrm{AgNO}_{3}$} \\
\hline 1.0 & 0.5 & $45.3 \mathrm{bc}$ & 56.2 \\
\hline 1.5 & 1.0 & $49.2 \mathrm{ab}$ & 61.5 \\
\hline 2.5 & 1.5 & 55.7 a & 69.6 \\
\hline 3.0 & 2.0 & $47.2 \mathrm{~b}$ & 59.0 \\
\hline 4.5 & 2.5 & $38.3 \mathrm{~cd}$ & 47.8 \\
\hline
\end{tabular}

Each value represents the mean \pm SD of three determinations. Letters indicate a significant Student's t test $(\mathrm{P}<0.05)$ between sampling points. 
conditions

Transfer to greenhouse

Matured and well-germinated cotyledon stage embryos with root poles and non-root poles were placed on culture tubes each containing $15 \mathrm{~mL}$ half strength EMM basal salts comprising of NAA (1.0-4.5 $\mu \mathrm{M})$ and $\mathrm{AgNO}_{3}(0.5-2.5 \mu \mathrm{M})$ for efficient rooting. After 1 month, the rooting results were recorded. NAA $(3.0 \mu \mathrm{M})$ alone in half strength EMM basal medium showed $48.8 \%$ of rooting frequency, whereas NAA $(2.5 \mu \mathrm{M})+\mathrm{AgNO}_{3}(1.5 \mu \mathrm{M})$ showed maximum rooting frequency of about 69.6\% (Table 4) (Figure 1h). Converted plantlets from somatic embryos were hardened and transplanted into soil under green house conditions.

\section{Discussion}

Somatic embryogenesis can be influenced by variety of physiological and developmental stage of the donor plants from which the initial explants are directly or indirectly formed. Direct somatic embryogenesis in safflower is earlier reported dependent on genotype, explant age, carbon source, ethylene (Mandal et al., 2001; Mandal et al., 2002) and cytokinin and auxins. Similar results were reported for somatic embryos that are formed by embryogenic cells, which arise from somatic cells of an explant, callus or suspension cells (Gaj, 2004). The concentration of auxin can affect somatic embryo development and morphology (Mandal et al., 2003) found that high frequency of safflower somatic embryos with optimum NAA, whereas IAA promoted the maximum number of somatic embryos per culture. However, previous reports say that auxins were found to be inhibitory for somatic embryogenesis in Oncidium (Chen and Chang, 2004).

Our results clearly demonstrates, significant increase in somatic embryogenesis of in vitro cultured somatic cells was found best by using different type of medium (MSG and EMM), inorganic $\left(\mathrm{KNO}_{3}, \mathrm{NH}_{4} \mathrm{NO}_{3}\right)$ and organic nitrogen sources (L-glutamine and Casein
Hydrolysate). Different stages of embryos were formed directly on the immature leaf surface without callus formation. However, in Chrysanthemum, kinetin was reported to induce somatic embryogenesis in combination with an auxin, particularly Indole Acetic Acid (IAA) (Tanaka et al., 2000). However, several reports have shown that involvement of polyamines, particularly in their free forms, in somatic embryogenesis has increased tremendously and has provided clues to improve plant developmental processes, including somatic embryogenesis, in a variety of economically important crops. Changes in high concentrations of polyamines were commonly observed in tissues undergoing somatic embryogenesis (Santanen and Simola, 1992; Yadav and Rajam, 1997; Minocha et al., 1999; Kevers et al., 2000). Related studies with wild carrot have shown that spermidine alone can restore embryogenesis in cultures treated with polyamine biosynthesis inhibitors, indicating a direct role of spermidine in somatic embryogenesis (Feirer et al., 1985; El Hadrami and D’Auzac, 1992). Spermidine plays important role in somatic embryogenesis has also been reported by (Tiburcio et al., 1985; Bonneau et al., 1995; Minocha et al., 1999; Cvikrova et al., 1999). Among the various results they observed a significant increase in spermidine levels associated with the formation of somatic embryos in tobacco, Picea abies, Euonymus europeaus L., Pinus radiate and alfalfa explants. Previous report says that spermidine was also the most abundant polyamine in conditions that allow cell cultures of Papaver somniferum to form embryo-like structures (Nabha et al., 1999). The cytokinins and auxin concentration applied on explants depends on the expression of the embryogenic and non-embryogenic callus.

Although, several reports concluded that the induction phase is independent of nitrogenous compounds while the somatic embryo developmental phase requires reduced nitrogen (Kamada and Harada, 1979). The embryogenic induction and differentiation is requirement 
of $\mathrm{NH}_{4}+$ was noticed by several other authors in different species and culturing systems (Walker and Sato, 1981; Meijer and Brown, 1987; He et al., 1989). Germinated, somatic embryos sprouted cotyledons with shoot poles and hypocotyls with root poles synchronously on semi solid medium containing $\mathrm{GA}_{3}$. When the germinated embryos were transferred to suitable rooting medium, the shoots with root poles or non-root poles produced frequency of adventitious roots. In earlier study, germinated embryos converted into complete plants were upon subculture to MS medium with NAA (Murashige and Skoog, 1962). However, in our study, NAA and $\mathrm{AgNO}_{3}$ had a positive effect on the frequency of shoot elongation with efficient rooting and on the survival of seedlings. In conclusion thus, as described above, this experiment standardized a simple and reliable protocol for somatic embryogenesis from transgenic immature leaf explants of safflower C. tinctorius L. cultivar NARI-6.

\section{Acknowledgements}

We are grateful to BDU for the institutional support and financial support provided by the Department of Biotechnology (DBT), Government of India, and the gift of rice chitinase gene by Dr. S. Muthukrishnan, Kansas State University, USA, is gratefully acknowledged.

\section{Conflicts of interest}

Authors declare that they have no conflict of interests.

\section{References}

Aydin, M.; Hossein Pour, A.; Haliloğlu, K.; Tosun, M. Effect of polyamines on somatic embryogenesis via mature embryo in wheat. Turkish Journal of Biology, v. 40, no. 6, p. 1178-1184, 2016. https://doi.org/10.3906/biy1601-21

Becwar, M. R.; Wann, S. R.; Johnson, M. A.; Verhagen, S. A.; Feirer, R. P.; Nagmani, R. Development and characterization of in vitro embryogenic systems in conifers. In: Ahuja, M.
R. (Ed.). Somatic cell genetics of woody plants. Dordrecht: Kluwer Academic, 1988. p. 1-18.

Bonneau, L.; Beranger-Novat, N.; Monin, J.; Martin Tanguy, J. Stimulation of root and somatic embryo production in Euonymus europaeus L. by an inhibitor of polyamine biosynthesis. Plant Growth Regul, v. 16, p. 5-10, 1995.

Chen, J. T.; Chang, W. C. TIBA affects the induction of direct somatic embryogenesis from leaf explants of Oncidium. Plant Cell Tissue Organ Cult, v. 79, no. 3, p. 315-320, 2004. https://doi.org/10.1007/s11240-004-4613-5

Conde, P.; Loureiro, J.; Santos, C. Somatic embryogenesis and plant regeneration from leaves of Ulmus minor Mill. Plant Cell Reports, v. 22, p. 632-639, 2004. https://doi.org/10.1007/s00299-003-0735-1

Cvikrova, M.; Binarova, P.; Cenklova, V.; Eder, J.; Machackova, I. Reinitiating of cell division and polyamine and monoamine levels in alfalfa explants during somatic embryogenesis. Physiologia Plantarum, v. 105, p.330-337, 1999. https://doi.org/10.1034/j.13993054.1999.105219.x

Dajue, L.; Mündel, H. H. Safflower (Carthamus tinctorius L.). In: Promoting the conservation and use of underutilized and neglected crops. 7. Gatersleben, Rome: Institute of Plant Genetic and Crop Plant Research, International Plant Genetic Resources Institute, 1996.

El Hadrami, I.; D’Auzac, J. Effects of polyamine biosynthetic inhibitors on somatic embryogenesis and cellular polyamines in Hevea brasiliensis. Journal of Plant Physiology, v. 140, no 1, p. 33-36, 1992. https://doi.org/10.1016/S0176-1617(11)81052-7

Feirer, R. P.; Wann, S. R.; Einspahr, D. W. The effects of spermidine synthesis inhibitors on in vitro plant development. Plant Growth Regulation, v. 3, no. 3/4, p. 319-327, 1985. https://doi.org/10.1007/BF00117589

Gaj, M. D. Factors influencing somatic embryogenesis induction and plant regeneration with particular reference to Arabidopsis thaliana (L.) Heynh. Plant Growth Regulation, v. 43, no. 1, p.27-47, 2004. https://doi.org/10.1023/B:GROW.0000038275.2 9262.fb

Griga, M. Morphology and anatomy of Pisum sativum somatic embryos. Biologia Plantarum, v. 45, no. 2, p. 173-182, 2002. https://doi.org/10.1023/A:1015176118719 
He, D. G.; Yang, Y. M.; Scott, K. J. The effect of macroelements in the induction of embryogenic callus from immature embryos of wheat (Triticum aestivum L). Plant Science, $\begin{array}{lll}\text { v. } 64, \quad \text { no. } 2, \quad \text { p. } 251-258, & 1989 .\end{array}$ https://doi.org/10.1016/0168-9452(89)90031-9

Kamada, H.; Harada, H. Studies on the organogenesis in carrot tissue cultures II. Effects of amino acids and inorganic nitrogenous compounds on somatic embryogenesis. Zeitschrift für Pflanzenphysiologie, v. 91, no. 5, p. 453-463, $1979 . \quad$ https://doi.org/10.1016/S0044328X(79)80259-7

Kevers, C.; Le Gal, N.; Monteiro, M.; Dommes, J.; Gaspar, T. H. Somatic embryogenesis of Panax ginseng in liquid cultures: a role for polyamines and their metabolic pathways. Plant Growth Regulation, v. 31, no. 3, p. 209-214, 2000. https://doi.org/10.1023/A:1006344316683 Kim, S. W.; Oh, S. C.; Liu, J. R. Control of direct and indirect somatic embryogenesis by exogenous growth regulators in immature zygotic embryo cultures of rose. Plant Cell, Tissue and Organ Cult, v. 74, no. 1, p. 61-66, 2003. https://doi.org/10.1023/A:1023355729046

Leelavathi, S.; Sunnichan, V. G.; Kumria, R.; Vijaykanth, G. P.; Bhatnagar, R. K.; Reddy, V.S. A simple and rapid Agrobacteriummediated transformation protocol for cotton (Gossypium hirsutum L.): Embryogenic calli as a source to generate large numbers of transgenic plants. Plant Cell Reports, v. 22, no. 7, p. 465470, 2004. https://doi.org/10.1007/s00299-0030710-X

Mandal, A. K. A.; Dutta Gupta, S. Direct somatic embryogenesis of safflower-a scanning electron microscopic study. Current Science, v. 83, p. 1138-1140, 2002. Available from: <http://www.currentscience.ac.in/cs/Downloads /article_id_083_09_1138_1140_0.pdf >.

Accessed on: Feb. 18, 2017.

Mandal, A. K. A.; Dutta Gupta, S. Somatic embryogenesis of safflower: influence of auxin and ontogeny of somatic embryos. Plant Cell, Tissue and Organ Cult, v. 72, p. 27-31, 2003. https://doi.org/10.1023/A:1021264403398

Mandal, A. K. A.; Dutta Gupta, S.; Chatterji, A. K. Factors affecting somatic embryogenesis from cotyledonary explants of safflower. Biologia Plantarum, v. 44, no. 4, p. 503-507, 2001. https://doi.org/10.1023/A:1013722116224 Meijer, E. G. M.; Brown, D. C. W. Role of exogenous reduced nitrogen and sucrose in rapid high frequency somatic embryogenesis in Medicago sativa. Plant Cell, Tissue and
Organ Culture, v. 10, no. 1, p. 11-19, 1987. https://doi.org/10.1007/BF00037492

Minocha, R.; Smith, D. R.; Reeves, C.; Steele, K. D.; Minocha, S. C. Polyamine levels during the development of zygotic and somatic embryos of Pinus radiata. Physiologia

Plantarum, v. 105, no. 1, p. 155-164, 1999. https://doi.org/10.1034/j.1399-

3054.1999.105123.x

Murashige, T.; Skoog, F. O. A revised medium for rapid growth and bioassay with tobacco tissue culture. Physiologia Plantarum, v. 15, no. 3, p. 473-497, 1962. https://doi.org/10.1111/j.13993054.1962.tb08052.x

Nabha, S.; Lamblin, F.; Gillet, F.; Lourain, D.; Fliniaux, M.; David, A.; Jacquin, A. Polyamine content and somatic embryogenesis in Papaver somniferum cells transformed with sam-1 gene. Journal of Plant Physiology, v. 154, p. 729734, 1999. https://doi.org/10.1016/S01761617(99)80251-X

Pradeep Kumar, S.; Ranjitha Kumari, B. D. Factors affecting on somatic embryogenesis of safflower (Carthamus tinctorius L.) at Morphological and Biochemical Levels. World Journal of Agricultural Sciences, v. 7, no. 2, p. 197-205, 2011. Available from: <https://www.idosi.org/wjas/wjas7(2)/16.pdf>. Accessed on: Feb. 18, 2017.

Santanen, A.; Simola, L. K. Changes in polyamine metabolism during somatic embryogenesis in Picea abies. Journal of Plant Physiology, v. 140, no. 4, p. 475-480, 1992. https://doi.org/10.1016/S0176-1617(11)80828$\mathrm{X}$

Sharma, S. K.; Millam, S. Somatic embryogenesis in Solanum tuberosum L.: a histological examination of key developmental stages. Plant Cell Reports, v. 23, no. 3, p. 115119, 2004. https://doi.org/10.1007/s00299-0040814-y

Sri Shilpa, K.; Dinesh Kumar, V.; Sujatha, M. Agrobacterium-mediated genetic transformation of safflower (Carthamus tinctorius L.). Plant Cell, Tissue and Organ Culture, v. 103, no. 3, p. 387-401, 2010. https://doi.org/10.1007/s11240-010-9792-7

Tanaka, K.; Kanno, Y.; Kudo, S.; Suzuki, M. Somatic embryogenesis and plant regeneration in chrysanthemum (Dendranthema grandiflorum (Ramat.) Kitamura). Plant Cell Reports, v. 19, no. 10, p. 946-953, 2000. https://doi.org/10.1007/s002990000225

Tiburcio, A. F.; Kaur-Sawhney, R.; Ingersoll, R. B.; Galston, A. W. Correlation between 
polyamines and pyrrolidine alkaloids in developing tobacco callus. Plant Physiology, $\begin{array}{llll}\text { v. 78, no. 2, } & \text { p. 323-326, } 1985 .\end{array}$ https://doi.org/10.1104/pp.78.2.323

Von Arnold, S.; Sabala, I.; Bozhkov, P.; Dyachok, J.; Filonova, L. Developmental pathways of somatic embryogenesis. Plant Cell, Tissue and Organ Culture, v. 69, no. 3, $\quad$ p. 233-249, 2002. https://doi.org/10.1023/A:1015673200621

Walker, K, A.; Sato, S, J. Morphogenesis in callus tissue of Medicago sativa: the role of ammonium ion on somatic embryogenesis. Plant Cell, Tissue and Organ Culture, v. 1, no. 1 p. 109-121, 1981. https://doi.org/10.1007/BF02318910
Yadav, J. S.; Rajam, M. V. Spatial distribution of free and conjugated polyamines in leaves of Solanum melongena L. associated with differential morphogenetic capacity: efficient somatic embryogenesis with putrescine. Journal of Experimental Botany, v. 48, no. 8, p. 1537-1545, 1997. https://doi.org/10.1093/jxb/48.8.1537

Zhang, Q.; Chen, J.; Henny, R, J. Direct somatic embryogenesis and plant regeneration from leaf, petiole, and stem explants of golden pothos. Plant Cell Reports, v. 23, no. 9, p. 587-595, 2005. https://doi.org/10.1007/s00299-004-0882$\mathrm{Z}$

License information: This is an open-access article distributed under the terms of the Creative Commons Attribution License, which permits unrestricted use, distribution, and reproduction in any medium, provided the original work is properly cited. 